\title{
Deism as a Heterodox Religious Identity with its Historical and Contemporary Aspects
}

Tarihsel ve Çağdaş Yönleriyle Heterodoks Dinî Bir Kimlik Olarak Deizm

\section{Şaban Ali DÜZGÜN}

Prof. Dr., Ankara University, Faculty of Theology, Ankara/Türkiye

duzgun@ankara.edu.tr $\mid \underline{\text { orcid.org/0000-0002-0447-9018 } \mid \text { ror.org/01wntqw50 | sabanaliduzgun.com.tr }}$

\author{
Article Information \\ Article Type \\ Research Article \\ Date Recieved \\ 31 October 2021 \\ Date Accepted \\ 27 December 2021 \\ Date Published \\ 31 December 2021 \\ Plagiarism
}

This article has been scanned with iTenticate software. No plagiarism detected.

Ethical Statement

It is declared that scientific and ethical principles have been followed while carrying out and writing this study and that all the sources used have been properly cited (Şaban Ali Düzgün).

Licensed under CC BY-NC-ND 4.0 license. 


\begin{abstract}
Deism from the beginning has positioned itself as a heterodox religious identity contrary to orthodoxy. In this regard, it is the review of established classical theological presuppositions regarding the following headings: conception of God; God-world relationship; religion-science relationship; ethical considerations regarding the problem of evil, etc. In these contexts, deism could be seen as a sort of religious self-criticism. As arose in British philosophical-theological circles, deism sounds to have resisted some conventional Christian presuppositions as put forward by E. Herbert of Cherbury, the father of English deism, in the forthcoming articles: "There is a supreme God. This sovereign deity should be worshipped. Virtue arises from the piety created by this worship. As the man is filled with wickedness, he needs repentance, which means communication with this sovereign Being. There is reward or punishment in the life to come." In the course of time, different kinds of deisms turned up, ranging from accepting God as a sublime creator alone and rejecting revelation, i.e., institutional religion, to those accepting religion on the condition that it should be compatible with reason. Samuel clarke mentions the arguments of different kinds of deists and skillfully criticizes them. Historical and contemporary deism have the following in common: "The compromise between truth of revelation and truth of reason; saving knowledge versus saving faith; rejection of institutional structures; glorification of reason and human nature; ethical rationality." With this doctrinal backdrop, hot debates on deism in Turkey have recently gotten new dimensions. Figures showing the rise of deism in recent years under an Islamist political rule makes the case all the more thought-provoking. The visibility of religion in the public sphere has increased, and the rate of religiosity would also be expected to increase. However, the result is quite the opposite. There is a widespread and remarkable secularization in conservative circles. After they got the political power and economic welfare, which enabled them to attain worldly glory, they have gradually left religious glory behind and glorified profanity. In this case, deism seems to take the form of secularized orthodoxy. Deists in Turkey, rather than rejecting revealed religion they want it to be compatible with reason, to demythologize it from supernatural narratives, and to find a way of getting rid of fanatical elements in the religion. They want to replace religious institutional authority with the authority of reason, which rests itself on innate ideas and a priori truths. They claim ethical rationality, which means ethical truths are accessible through reasoning. My study tackles some statistical data specifically signifying why youngsters tend to claim to be deists. Some surveys among high school students have been included in the study and due evaluations have been made. It seems sectarian identities, radical voices, authoritative religious language, blockades to freedom of speech, a dichotomy between religious and scientific facts in the curricula and mythological religious language are among the reasons counted by the youngster to reject conventional religion and embrace deism. The mainstream theological tradition of Islam is quite familiar with deistic claims. The discussions on deism will finally bring the enlightened minds together with the reasonable religious line.
\end{abstract}

Anahtar Kelimeler: Deism, God, Secularized orthodoxy, Deism as a heterodox identity.

\title{
Öz
}

Deizm başından beri kendini ana akım dinî kabullere karşı heterodoks dinî bir kimlik olarak konumlandırmış, felsefe ve teolojinin temel düşünce üretim alanları olan Tanrı tasavvurları, Allah-âlem ilişkisi, din-bilim ilişkisi, kötülük meselesinden kaynaklı ahlakî tartışmalarda geleneksel kabullere aykırı görüşler ileri sürmüştür. Bu yönüyle deizm, dinin kendi içinden bir eleştirisidir. İngiltere'de deizmin babası olarak isimlendirilen E. Herbert of Cherbury'nin deizmin beş ilkesi bu eleştirinin en başat örneğidir. Ona göre; 1. Yüce bir Tanrı vardır, 2. Bu yüce Varlığa ibadet edilmelidir, 3. Erdem ibadetin yarattığı bir değer olduğu için din ve ahlak arasında doğrudan bir ilişki vardır, 4. İnsanlar zayıf yaratıldıkları için tövbe ihtiyacındadırlar; bu da Tanrı'yla iletişime açılık demektir, 5. Ölümden sonraki hayatta ceza ve mükâfat vardır. Deizmin iddiaları zaman içinde değişikliğe uğramıştır. Bu değişimi, farklı deizm iddialarını tasnif eden ve eleştiren Samuel Clarke'ta görmek mümkündür. Bununla birlikte, deistler şu konularda ortak fikre sahiptirler: imanın kurtarıcilığına karşı bilginin kurtarıcılı̆̆ı esastır; kurumsal dinî yapılar reddedilmelidir; akıl ve insan doğası yüceltilmelidir; ahlak akılla temellendirilebilir; (vahyin imkânını kabul eden deistlere göre) vahyin doğrusu ile aklın doğrusu uyum içinde olmalıdır. Türkiye'de deistler dini reddetmekten daha çok onun akılla uyumunu talep etmekte, hurafelerden arındırılmasını ve radikal söylemlerden temizlenmesini istemektedirler. Kurumsal dinî otorilerin yerine, insanın aklına ve doğasına yaslanan doğruları önermektedirler. Bu doktrin temeline ek olarak Türkiye'de deizm ilginç veriler ve sonuçlar üretmektedir. Türkiye'de muhafazakâr bir yönetim iş başındayken deizmin artış kaydetmesi çok çarpıcıdır. Kamusal alanda dinin daha fazla görünür olmasına rağmen, deizmin ve sekülerleşmenin artması, din-siyaset ilişkisinin çok sıkı kurulduğu ülkelerde dine yabancılaşma gibi bir sonucun ortaya çıktığı tezini bir kez daha doğrulamış görünmektedir. Bu çalışma deizmin farklı iddialarını dikkate alarak ve Türkiye'de lise öğrencileri arasında yapılan araştırmalara dayanarak şu sonuçları okuyucuyla paylaşmaktadır: Mezhep farklılığının tetiklediği şiddet, radikal söylemler, buyurgan din dili, mitolojik anlatımlar genç 
zihinleri geleneksel olarak tevarüs ettikleri birikimi yeniden değerlendirmeye itmektedir. Kendilerini dinin dışında konumlandırmak istemeyen bu zihinler, yeni bir dini kimliği tercih etmektedirler. Bu kimlik bugün artık heterodoks bir kimlik olarak kendini göstermektedir. Bu aynı zamanda sekülerleşmiş bir ortodoksinin ortaya çıktığının da açık göstergesidir.

Keywords: Deizm, Tanrı, Sekülerleşmiş ortodoksi, Heterodoks bir kimlik olarak deizm.

\section{Deism Revisited: Philosophical and Theological Backdrop}

The first thing to know about deism is that it was neither uniform in history nor today. In the same way, neither in the beginning nor at present has it a clear-cut monolithic doctrine and methodology. Theoretically, there are different kinds of deisms with different arguments and justifications; and in the social stage, there are quite various deistic forms and their motives behind.

Edward Herbert of Cherbury, the father of English deism ${ }^{1}$ (1583-1648) counts five beliefs of deism: 1. "There is a supreme God", 2. "This sovereign deity should be worshipped", 3. "The connection of virtue with piety is the most important part of religious practice", 4. "The minds of men have always been filled with horror for their wickedness; their vices and crimes have been obvious to them; they must be expiated by repentance" and, 5. "There is reward or punishment after this life". 2

A critic of deism Samuel Clarke (1675-1729) mentions four groups of deists of his time with their arguments and assesses them: The first group believes in a God who created the world as an eternal, infinite, potent, and intelligent Being. He makes the world like a clock and takes it over, but he has no connection with the world and is not concerned with what is happening over there. S. Clarke's answer to this deistic claim is as follows: First, science has shown that, due to the nature of matter, it cannot make the laws to which it is a subject. Therefore, the matter needs God, who continually cares for it. Secondly, a God who is not concerned with the world implies that $\mathrm{He}$ neither has knowledge nor the power or will and wisdom to intervene when necessary. Such a conception of God has no appeal for us. The second group admits that God is interested in the universe, and there is no place for morality in this concern. According to this group, God's volition is not affected and changed by the appeals from earthlings. God's volition directly corresponds to cosmic events, and it is not an object of individual persons' desires and hopes. An act that is moral to us is neutral in the sight of God. S. Clarke criticizes this second group as follows: First, this group did not understand that morality is a matter of fixed, eternal relations. Second, denying the existence of God's moral attributes requires denial of either God's wisdom or power. The third group accepts God's moral attributes but denies the immortality of the human soul, and they do not give any moral functionality to the attributes of God. Such a claim leads to the removal of all

For detailed analysis of English deism and its theological assessment see: Meryem Özdemir Kardaş, Deistik Argümanlara Karşı Vahyin İmkân ve Gerekliliği: 18. Yüzyıl İngiliz Deizmi ve Kelami Açıdan Analizi (The Possibility and Necessity of Revelation Against Deistic Arguments: 18th Century English Deism and Its Theological Analysis) (Unpublished PhD thesis), Ankara 2021.

2 George Williams, "Socinianism and Deism: From Eschatological Elitism to Universal Immortality", Historical Reflections/Reflexions Historiques, Winter 1976, vo. 2, no. 2 (1976), p. 1. 
attributes of God. The fourth group acknowledges that religions can give us some moral doctrines, but they object to the claim that this doctrine can only be represented by Christian revelation. ${ }^{3}$

Jean Jacques Rousseau (1712-78) emphasized the weight of emotions rather than reason in deism as defended by Voltaire (1694-1778) whose "life-long obsession was the eradication of all organized religion, with its superstition, fanaticism, intolerance, and obscurantism". "Contrary to excessive confidence of philosophes ${ }^{5}$ in reason, Rousseau focused on the interior life of a human kind and on the role of the heart, conscience, sentiment, feelings, and moral intuition in the conduct of moral life. Reason was not enough. Rather, conscience as the function of man's interiority and sentiments tells us what our moral obligations are. God reveals himself not only through nature, but speaks to us through conscience and our sentiments". ${ }^{6}$

In addition to these varieties in doctrine and methodology, we can list the dominant common features of deism as follows:

\subsection{The Compromise between Truth of Revelation and Truth of Reason}

A group of deists asserts that humankind need prophetic truths in addition to the facts discovered by reason. One of the pioneers of deism Benjamin Whichcote (1609-1683) specified the motto of this kind as follows: "Reason has the capacity to discover what is natural and to accept what is supernatural." However, he adds: "The precondition for what is accepted as supernatural by us is that it passes the test of conformity with nature and reason. Otherwise, it should be rejected. The final aim of them is to reconcile findings of reason and the claims of revelation. The compromise between reason and revelation manifests itself in relations as sobriety/temperance (between body and mind) as righteousness/morality (between man and man), as godliness/piety (between God and humankind). ${ }^{7}$

\subsection{Saving Knowledge versus Saving Faith}

Historically there are deists who replaced the saving faith with saving knowledge. To illustrate, Nicholas Cusanus criticizes Christianity as the intolerant and monopolistic structure that replace faith with knowledge. The expression 'saving faith' necessarily makes people dependent on religions, but 'saving knowledge' renders them, independent individuals. Faith has to show people how to live in a harmonious way by following their true nature and the reason given them by God to illuminate their way. "The intellect was created by God with the aim of enabling man to come

For more detail see: Samuel Clarke, A Demonstration of the Being and Attributes of God and Other 22 Writings (1705), ed. Ezio Vailati, Cambridge University Press, 1998. For the pioneer figures of deism and the basic doctrine see: Şaban Ali Düzgün, "Deizm: Öncü İsimler ve Temel Doktrin”, Din Karşıtı Çağdaş Akımlar ve Deizm ("The Pioneer Figures of Deism and the Fundamental Doctrine", in Contemporary Movements Against Religion and Deism) (ed. V. Sönmez, B. Kıyıcı and Metin Yıldız), Ensar Yay. Van, 2017, pp. 3-15.

Raul J. Bonoan, "The Enlightenment, Deism and Rizal”, Philippine Studies, First Quarter 1992, vol. 40, no. 1, p. 55

The French enlightenment thinkers called themselves philosophes, not philosophers.

Raul J. Bonoan, ibid., p. 54

For detail see. Jay Gomer Williams, The Life and Thoughts of Benjamin Whichcote, (PhD Thesis) Columbia University, 1964. 
to know God." Including knowing God, intellect manifests its capability in orientating man in his worldly journey.

\subsection{Rejection of Institutional Structures}

Deists reject institutional authority they consider as the source of fanaticism and intolerance and replace it with the final authority of rational knowledge. They suggest the language of persuasion be favored instead of dictation and imposition. They see institutional structures such as religion, sects/religious denominations as the most significant obstacles to independent thought.

The contradiction between institutional religion and God, between state-religion togetherness and science, between true belief in God and mythologies, between the God of religions and God of Creator of the universe, can be seen in the declaration of Deism Association. ${ }^{9}$

\subsection{Glorification of Reason and Human Nature}

Deists claim that reason, logic, and human nature are truly glorified only within deism. Their emphasis on rationality brought them in line with the idea of innate ideas and obvious logical truths (Cambridge Platonists). Therefore, they are in favor of moral rationalism, claiming moral truths can rationally be discovered. As moral truths are mental truths, reason alone can discover the facts contained in natural religion. It is inconceivable that religion has mysteries and secrets, which a human being cannot understand. According to deists, savior knowledge is knowledge to be based on reason and common sense.

\subsection{Religion within the Boundaries of Reason}

The title of the books penned by the enlightenment thinkers on religion denotes that the pivotal character ascribed to religion is that it should be sited within the boundaries of reason. To them, religion must be 'natural', 'reasonable' and 'free of superstitions'. John Toland's Christianity not Mysterious (1696) illustrates the prominent character ascribed to religion at that time.

\subsection{Ethical Rationality and Ethically Transcendent God}

Deism portrays absolute transcendence in which God manifests Himself in the universe, not in human life. The ethical imperfections in the world can be explained either by reference to humans or to God. The fact that no imperfection can be ascribed to God brings deists to a logical conclusion that the evil in the world is a human affair. This is ethical rationality, which leads deists to believe that God is not interested in human life in any way; otherwise, the world would be a very different if the case were the other way.

\section{The Rise of Deism in Turkey and The Possible Reasons Behind}

Islam has many historical and social manifestations. It has basic creedal and ethical principles that blend the historical and social and thus create what is proper for the spirit of the time. These principles, which aim to ensure the continuation of existence in the best form, become archaic

Martin Thurner, "Die Sinnlichkeit Als Selmstdarstellung Des Geistes: Die “Aeginmata' Des Cusanus”, Recherches de théologie et philosophie médiévales, Vol. 71, No. 2 (2004), p. 373.

https://deizmdernegi.org/deizm-dernegi-deklarasyonu/ 
and need reformulation when it cannot adapt to the spirit of the time. It seems we are passing through times when a great gap has arisen between these principles and the spirit of the time.

Turkey's imperial and republican experiences place it in a different place from other Islamic countries, which requires a sui generis religious and societal stand. When we consider this backdrop, it becomes possible to understand the new progressive demands. Different tendencies that sometimes question the current orthodox religious identity, sometimes put it on the line of reasonableness or reject it, have always existed in the society.

\subsection{A Paradox: Increased Visibility of Religion in Public Sphere and Rise of Deism}

The rise of deism in Turkey despite the increased visibility of religion in the public sphere in recent years seems as a paradox and requires further analysis. It has been historically proved that any initiative to instrumentalize religion eventually harms religion most; and Turkey is no exception.

There is a widespread and remarkable secularization in conservative circles. ${ }^{10}$ After they got the political power and economic welfare, which enabled them to attain worldly glory, they gradually left religious glory behind and justified profanity. The conservatives have the habit of handling every issue under a religious rubric and penetrate religiosity into every issue they come across, which creates religious fatigue, as specified by a Turkish theologian Necdet Subaşı. The reason why we do not witness sincere piety is religiosity taken over by popular culture, according to the author. ${ }^{11}$ Apparently, religion occupied every space but it dwells nowhere in its real meaning.

\subsection{Deism as a Heterodox Religious Identity}

Deism from the beginning has been seen as a heterodox religious identity rather than an atheistic one. It is not as easy for a person to claim to be an atheist as to claim to be a deist.Considering this historical backdrop, deism is still referred as a kind of religiosity and makes it easy for someone to claim to be a deist. This is especially true in societies with strong religious conventions and traditions where the social construction of deism is much stronger than its justified philosophical arguments.

Interestingly enough, unorthodoxies like Arianism and Socinianism have the same tenets with deism like rejecting the doctrine of trinity and divinity of Christ. ${ }^{12}$

\subsection{Deism as the Secularized Orthodoxy}

Deism is the secularization of theology from within. A theology that cannot make peace with science and the world, and cannot meet the basic principles of rationality is to create a different form of being scientific in itself. It is the review of classical theological presuppositions regarding

10 For further analysis of religion-secularization relation see: Volkan Ertit, Sekülerleşme Teorisi, (The Theory of Secularization), Liberte Pub. İstanbul, 2019.

11 See more detail: Necdet Subaşı, “'Din Yorgunluğu' ya da Gündelik Popüler Kültürün Tükettiği 'ìslami' Yorumlar”, Gelenek ve Modernite Arasinda İslam Yorumlar, ("'Religious Fatigue' or 'Islamic' Interpretations Consumed by Daily Popular Culture", Islamic Interpretations between Tradition and Modernity) ISAV: Konya 2017, ss. 223-229.

12 See George Williams, Socinianism and Deism: From Eschatological Elitism to Universal Immortality, Historical Reflections/Reflexions Historiques, Winter 1976, vo. 2, no. 2 (1976), pp. 265-290. 
the relationship between God and the world and how the relationship between religion and science should be. It is a religious self-criticism.

As the secularized orthodoxy and a heterodox religious identity, deism in Turkey presupposes the followings:

Human nature is inborn encoded to reveal the natural laws through his reason and experience and declare it as a universal inductive law. Some traditional religious claims that go contrary to factual statement on nature creates a mental dichotomy. Some religious people pervert human reason and experience; thus, religion, according to deists, distorts the natural flux of events. This also creates a rationale for those claiming to be deists.

Some deists in Turkey, rather than rejecting revealed religion they want it to be compatible with reason, to demythologize it from supernatural narratives, and to find a way of getting rid of fanatical elements from the religion. They want to replace religious institutional authority with the authority of reason, which rests itself on innate ideas and a priori truths. They claim ethical rationality, which means ethical truths are accessible through reasoning. The claims that there are some unexplainable elements within a religion or supra-natural elements or secrets within the religion are rejected. They claim that in order to get the knowledge of God, we do not need mediators who first introduce people to the fear of God, then they offer ways to save people from this fear.

Deism in Turkey serves as a protest movement against intolerance prevalent among religious groups. If religion is irrational, intolerant, and sectarian, it naturally cannot find any positive response on the public side. Some youngsters' claim that they are deists indeed is just an objection to traditional religion. They reject religion as it is understood and practiced in the popular area, and they are taking revenge of the dogmatic education imparted by the family.

Deism debates in Turkey may be taken as one of the earlier signals of a sui generis enlightenment. The Kantian enlightenment motto of sapere aude currently manifests itself in many forms as the signal of this enlightenment. Sometimes in the form of reason, sometimes as human nature, and sometimes as the rejection of what has traditionally been inherited.

The dichotomy between religious and scientific facts in the high school curriculum creates a vortex for young minds. This dichotomous and dual character of curricula in Turkey, such as creationism/intelligent design versus Darwinism, creates this schizophrenic mind in the educational system.

The aspiration to distance himself/herself from the negativities created by Islamist politics. Many people who want to distance themselves from existing political negativities want to define themselves with a different identity. To claim to be deist fitted the case best.

\subsection{Youngsters Alienation to Religion and Possible Causes Behind}

Youngsters shifting from orthodox Islamic mainstream tend to define themselves as 'deist' increasingly in recent years. Why is that? What are the historical, social, religious, cultural and political implications of this orientation? Why does deism as a new heterodox religious identity 
arise? What does it reject? What does it highlight? It seems there are more than one reason to these questions.

Considering these questions, the following factors could be seen among the crucial ones that lead youths to protest, object and reject what is presented to them as mainstream Islam.

- Sectarian identities that overshadow the search for truth. Islam of identity precedes the Islam of truth.

- Radical voices and acts of some Muslim groups.

- Over-idealization of Islam. This creates a huge gap between ideal and phenomenal/real one. Unrealized ideals radicalize people. Deism is one of these radical forms of reaction. Deism is a form of resentment to religion in this case.

- Authoritative religious language. Religious language is authoritative rather than convincing; legal and judiciary rather than ethical; exclusive rather than inclusive.

- Blockades to freedom of speech. It is almost improbable to declare any opinion outside the orthodox line.

- The dichotomy between religious and scientific facts in high school curriculum such as creationism/intelligent design versus Darwinism creates a schizophrenic mind in the educational system.

- Rejection of state-sponsored religiosity.

- The mythological and superstitious language used by a traditional religious narrative.

\subsection{Some Statements of the Youths Claiming to be Deist}

Qualitative surveys conducted among high school students exhibit the overall objection of the students to religion as it is understood and practiced in Turkey. Some of the students' statements are below:

- The religious rhetoric of so-called Muslim scholars of today estranges me from the faith.

- Religion is using the language of threat and fear in order to keep people away from evil acts.

- As religion is resistant to changing life and its requirements, there is no need it at all.

- All religions are not but the sources of chaos and killings.

- Religion is a kind of opium. It is an instrument and source of legitimacy for those who have the intention of exploiting the sincere feelings of the people.

- Even on the identity card of a baby, religion is designated. How could it be possible for a baby to have a religion? This shows that religion is something inherited, not a matter of choice.

- There are good people outside Islam, but they are believed to go to hell just because they are not Muslims. This is not fair.

- The fact that religion is so efficient in political affairs does not fit my mind. 
- Having sent many religions, if God claims only one of them is viable and true, there must be something wrong with the religion itself.

- Religion tells us we are in an ongoing exam in the World. Why is this exam? Why did the omnipotent God not annihilate the devil in the beginning?

- If there is an omnipotent, omniscient, and all-good God, why is there evil and all these sufferings?

- Any religion that does not say anything about child abuse but strictly prohibits alcohol indeed says nothing to me.

- To claim that prophets are human on the one hand and to say they are immune to sins on the other is not but a contradiction. ${ }^{13}$

\section{Conclusion}

The reason why the debates about deism is so controversial in Turkey is that it increased during the period of a political rule whose primary feature is deemed as piety. But the merger of politics and religion almost creates the same result: Alienation to religion. With the increasing visibility of religion in the public sphere, hot debates on the reasonableness of religion on the one hand and the legitimacy of what religious people do on the other have flared up. It is sociologically well established that secularization is expected to abolish religion. Conversely, it is thought that religion's gaining ground will abolish secularization. However, we are faced with an interesting situation in Turkey. Despite the areas religion has won, the fact that it did not give what is expected of it increased secularization. In this sense, deism is a form of secularization some devout people adhere. After all, deism is a religious identity, but quite different from the thought represented by the mainstream orthodox religiosity. As with all identities, the content of this religious identity is secondary. The primary thing is that they feel the need to identify themselves with an identity outside of the present.

Although the Presidency of Religious Affairs does not seem to see deism as a serious threat, it actually conducts serious workshops to discuss where the issue stems from and what can be done. Theology Faculties take the issue much more seriously. Politics tries to gloss over the issue in order not to see the consequences it caused.

As Turkey's historical-theological background, i.e. Hanafi-Mâturîdî tradition, is predominantly built on a rational line, deism's claims is not new to Turkish mind and seem very unlikely to gain permanent ground in Turkey. There is a huge difference between the irrational theology that deism opposed in Europe and the rational theology initiated by Mutazila and continued with Muslim philosophers in philosophy and Hanafî-Mâturîdî line in theology. Therefore, deism does

13 For further questions that are deemed to push students to deism see Fatma Günaydın, "İmam Hatip Liselerinde İnanç Soru(n)ları", Din Karşıtı Çağdaş Akımlar ve Deizm, ("Belief Problems in Religious High Schools”, in Contemporary Movements Against Religion and Deism) Ensar Yay. Van, 2017, s. 321; See for a detailed survey conducted about belief problems including deism, Ayşe Betül Akdemir, "Öğrencilerde İnanç Problemlerine Neden Olan Faktörlerin Belirlenmesi" (“Determining the Factors Causing Belief Problems in Students”), dergiabant, Spring 2020, vol. 8, no. 1 , pp. 318-342. 
not propose a novel horizon to a Turkish-Muslim mind on this front. However, it seems it has new offers and serious challenges to traditional orthodoxy.

Deism's distance from prophethood creates an aversion and abhorrence. Furthermore, the language they use is philosophically-theologically quite weak; and they are not aware of deep Muslim theological and philosophical tradition.

It is hoped that all these discussions will activate the processes that will reveal an individual and social theory that grounds religion on a reasonable line and offer individual freedoms and social equity for all.

\section{Acknowledgements}

The author is on the editorial board of Kader. However, in this issue, in which the author's article was published, the editorial duties and authorizations of the author were suspended. Thus, the principle of double-blind refereeing was complied with. 


\section{Bibliography}

Akdemir, Ayşe Betül. “Öğrencilerde İnanç Problemlerine Neden Olan Faktörlerin Belirlenmesi” (Determining the Factors Causing Belief Problems in Students). dergiabant, Spring 2020, vol. 8, no. 1.

Bonoan, Raul J. “The Enlightenment, Deism and Rizal”. Philippine Studies, First Quarter 1992, vol. 40 , no. 1 .

Clarke, Samuel. A Demonstration of the Being and Attributes of God and Other 22 Writings (1705). ed. Ezio Vailati, Cambridge University Press, 1998.

Düzgün, Şaban Ali. Deizm: “Öncü İsimler ve Temel Doktrin”, Din Karşıtı Çağdaş Akımlar ve Deizm ("The Pioneer Figures of Deism and the Fundamental Doctrine", in Contemporary Movements Against Religion and Deism). (ed. V. Sönmez, B. Kıyıcı and M. Yıldız), Ensar Yay. Van, 2017.

Ertit, Volkan. Sekülerleşme Teorisi, (The Theory of Secularization). Liberte Yay. İstanbul, 2019.

Günaydın, Fatma. “İmam Hatip Liselerinde İnanç Soru(n)ları”, Din Karşıtı Çağdaş Akımlar ve Deizm, ("Belief Problems in Religious High Schools", in Contemporary Movements Against Religion and Deism). (ed. V. Sönmez, B. Kıyıcı and M. Yıldız), Ensar Yay. Van, 2017.

Kardaş, Meryem Özdemir. Deistik Argümanlara Karşı Vahyin İmkân ve Gerekliliği: 18. Yüzyıl İngiliz Deizmi ve Kelami Açıdan Analizi (The Possibility and Necessity of Revelation Against Deistic Arguments: 18th Century English Deism and Its Theological Analysis). (Unpublished PhD thesis) Ankara, 2021.

Subaşı, Necdet. “Din Yorgunluğu' ya da Gündelik Popüler Kültürün Tükettiği ‘'̇slami’ Yorumlar”, Gelenek ve Modernite Arasinda İslam Yorumları, ("Religious Fatigue' or 'Islamic' Interpretations Consumed by Daily Popular Culture". Islamic Interpretations between Tradition and Modernity). Konya: ISAV,2017.

Thurner, Martin. “Die Sinnlichkeit Als Selmstdarstellung Des Geistes: Die “Aeginmata' Des Cusanus”. Recherches de théologie et philosophie médiévales. Vol. 71, No. 2 (2004).

Williams, Jay Gomer. The Life and Thoughts of Benjamin Whichcote. (PhD Thesis) Columbia University, 1964.

Williams, George. “Socinianism and Deism: From Eschatological Elitism to Universal Immortality”. Historical Reflections/Reflexions Historiques, Winter 1976, vo. 2, no. 2 (1976).

\section{Websites}

https://deizmdernegi.org/deizm-dernegi-deklarasyonu/ 